\title{
Mathematical Modelling of Water Absorption Kinetics Using Empirical and Phenomenological Models for Millets
}

\author{
Ankit Paliwal, Neha Sharma
}

\begin{abstract}
Steeping is one of the major pre-treatment which can reduce anti-nutritional factors without losing dietary fibre and polyphenols unlike in dehulling. In the current study water absorption characteristics of pearl millet and finger millet during steeping at temperature $10^{\circ} \mathrm{C}, 20^{\circ} \mathrm{C}, 30^{\circ} \mathrm{C}, 40^{\circ} \mathrm{C}$ and $50^{\circ} \mathrm{C}$ were calculated. Two empirical and one phenomenological model were used to simulate water absorption kinetics. Both the Peleg model and Omoto model were found adequately capable to predict water uptake of pearl millet and finger millet under the designed experimental conditions with regression coefficient more than 0.96. Due to comparatively high variation in grain volume during the hydration process and longer process time, sigmoidal model cannot be utilized for calculation of effective diffusivity and activation energy. Peleg's rate constant shows an inverse relationship with steeping temperature. The activation energy was calculated by substituting effective diffusivity with reciprocal of Peleg's rate constant in Arrhenius equation and was found 25.97 $\mathrm{kJ} / \mathrm{mol}$ and $32.36 \mathrm{~kJ} / \mathrm{mol}$ respectively for pearl millet and finger millet.
\end{abstract}

Keywords: Hydration Kinetics, Millet, empirical model, phenomenological model, Peleg model, Omoto model

\section{INTRODUCTION}

Millet is a group of cereal crops grown in different parts across the globe. Its adaptability to severe climatic conditions has added to its popularity in temperate countries. India is among the leading countries which produce and utilise millet as a popular cereal crop, other than wheat and rice. Its production is around $16.8 \%$ of total cereal production in India. Major varieties of millets grown in India are Sorghum, Pearl millet, Foxtail millet, Little millet, Finger millet, Proso millet, Barnyard millet and Kodo millet. Pearl (Pennisetum glaucum) and finger (Eleusine coracana) millet comprise of about $20 \%$ and $4 \%$ of total Indian millet production respectively. Besides containing considerable proportions of starch, proteins and non-starch carbohydrates, millet grains are generally assumed to be also rich in polyphenols and trace elements [1],[2],[3],[4],[5]. The nutritive value of millet has been found to be hindered by a number of anti-nutritional

Revised Manuscript Received on October 30, 2019.

* Correspondence Author

Ankit Paliwal*, Amity Institute of Food Technology, Amity University Uttar Pradesh, Noida, India.

Neha Sharma, Amity Institute of Food Technology, Amity University Uttar Pradesh, Noida, India.

(C) The Authors. Published by Blue Eyes Intelligence Engineering and Sciences Publication (BEIESP). This is an open access article under the CC BY-NC-ND license (http://creativecommons.org/licenses/by-nc-nd/4.0/) factors, namely tannin, oxalate, phytate, protease and amylase inhibitors [6],[7]. Post-harvest pre-milling treatments, namely dehulling, steeping, germination, fermentation, heat-moisture treatment can significantly decrease or remove these anti-nutritional compounds, which are mostly located in the hull [4],[8],[9],[10],[11]. Dehulling has been the most common practice for removal of antinutritional factors [12]. However, simultaneous removal of important fibre and polyphenolic compounds is a major drawback of dehulling. Tempering or steeping in water is another pre-treatment applied prior to millet flour milling process [9]. It is a slower process, in which water absorption and intra-endosperm moisture migration are controlled by the diffusion process. During the steeping process, the prevailing aqueous atmosphere solubilises the phenolic compounds present in the grains and facilitate their leaching out. The change in colour of the steep liquor is evident during steeping [13],[14]. Water absorption kinetics during steeping has been extensively studied for traditional cereals, pulses and legumes [15],[16],[17],[18]. Pre-set conditions during water absorption like temperature, steeping time and water to grain ratio affect the water absorption capacity, grain volume change as well as water absorption rate. Which could further affect the final product quality or next process [17],[19].

Mathematical modelling is one of the most common practices for process designing and optimization. Despite the presence of various advanced statistical tools and programming, mathematical models dominate the field due to their simplicity and ease of usage [20],[21]. Mathematical models have been applied successfully in studies of hydration kinetics of rice [22],[23], barley [24], corn [23], soybean [25], chickpea [26] and various other beans [15],[18], and seeds [27]. Empirical models are the most widely used mathematical models for hydration kinetics studies as they are very simple and mostly focused on water uptake rate[28]. Peleg's equation is the most common empirical model, which is non-exponential, two-way parameter equation[29]. Initial lag phase during hydration cannot be explained by the Peleg's equation, which generally occurs due to formation of the coating layer. The sigmoidal model was proposed for better understating of such phenomena [15],[28]. A phenomenological model considers such mass transfer phenomena like diffusion, convection, and water concentration inside the grain. Phenomenological model could be based upon lumped parameters like water distribution inside the grain or distributed parameters like concentration gradient inside the grain [16],[22],[25],[30]. Omoto model is based upon lumped parameter considering uniform water concentration inside the grain [31]. 
No work on phenomenological modelling of steeping of millet could be found in the currently available literature. However, industrial process optimization of millet steeping would be benefitted by researches through mathematical approaches. Process and quality parameters like moisture content, temperature, density and diffusion can be suitable

variables for applying the mathematical approach for steeping process modelling. In this study, two empirical mathematical models, namely Peleg's model and sigmoidal model and one phenomenological model of Omoto were compared for studying hydration kinetics during steeping of pearl and finger millet.

\section{MATERIALS AND METHODS}

\section{A. Sample preparation}

Pearl millet and finger millet were procured from the Indian Council of Agricultural Research, Pusa, New Delhi. They were manually cleaned to separate foreign matter and screened to get rid of particulate dust and lighter particles. The seeds were then stored at $4{ }^{\circ} \mathrm{C}$ in sealed polypropylene (PP) bags until further use.

\section{B. Physical properties}

A hundred kernels from each sample were randomly selected and measured in three perpendicular directions for length (L), width (W) and height $(\mathrm{H})$ using a digital calliper (Mitutoyo) with an accuracy of $0.01 \mathrm{~mm}$. The geometric mean diameter $\left(D_{g}\right)$, surface area $(S)$, sphericity $(\varphi)$, and volume $\left(\mathrm{V}_{\mathrm{g}}\right)$ were calculated using the following relationships [28]:

$$
\begin{aligned}
& D_{g}=(L W H)^{\frac{1}{3}} \\
& S=\frac{\pi(W H)^{0.5} L^{2}}{2 L-(W H)^{0.5}} \\
& \varnothing=\frac{D_{g}}{L} \\
& V_{g}=\frac{\pi W H L^{2}}{6\left[2 L-(W H)^{0.5}\right]}
\end{aligned}
$$

\section{Steeping procedure}

Twenty grams of sample was soaked in $80 \mathrm{ml}$ distilled water and incubated at $10^{\circ} \mathrm{C}, 20^{\circ} \mathrm{C}, 30^{\circ} \mathrm{C}, 40^{\circ} \mathrm{C}$ and $50^{\circ} \mathrm{C}$ in a temperature-controlled water-bath with the temperature accuracy of $\pm 1{ }^{\circ} \mathrm{C}$. Steeping was continued till collection of representative samples at $30^{\text {th }}, 60^{\text {th }}, 120^{\text {th }}, 180^{\text {th }}, 240^{\text {th }}, 300^{\text {th }}$, $360^{\text {th }}, 420^{\text {th }}, 480^{\text {th }}, 720^{\text {th }}, 960^{\text {th }}, 1200^{\text {th }}$ and $1440^{\text {th }}$ min. The excess water was removed by placing samples immediately on a blotting paper and weighed for determination of water uptake. Water absorption capacity (WAC, \%) of the samples were calculated using the following equation [17]:

$$
W A C=\frac{W-W_{o}}{W_{o}} \times 100
$$

Where $W$ is sample grain weight at time $t, W_{o}$ is initial sample grain weight

\section{Mathematical Modelling}

The empirical model proposed by Peleg is one of the most common mathematical models which is used for the understanding of water absorption and desorption. It is most extensively used to explain water absorption and desorption behaviour of both cereal and non-cereal grains. It is a two-parameter sorption equation, which could be stat as:

$$
M_{t}=M_{0} \pm \frac{t}{K_{1}+K_{2} t}
$$

Where $t$ is steeping time (hours), $\mathrm{M}_{\mathrm{t}}$ is moisture content (dry basis) at time $t, M_{0}$ is initial moisture content (dry basis), and
$K_{1} \& K_{2}$ are the constants. $K_{1}$ is Peleg rate constant (1/h\%) which is related to sorption rate at the beginning of water absorption, while $\mathrm{K}_{2}$ is Peleg capacity constant which shows maximum water holding capacity at the end of water absorption process, the time when the sample is in equilibrium with surrounding [32].

The same equation could also be re-written as:

$$
\frac{t}{M_{t}-M_{o}}=K_{1}+K_{2} t
$$

The above equation is like a linear equation $y=m x+c$. Hence a plot between $t /\left(M_{t}-M_{0}\right)$ versus steeping time $t$, could give the values of constant $\mathrm{K}_{1}$ and $\mathrm{K}_{2}$.

While the Peleg model works well for homogenous models, it is not that much accurate for heterogeneous materials like grains. Water absorption behaviour of the outer bran layer is significantly different from the endosperm. According to Paquet-Durand et.al [33], Peleg model for water sorption should be applied for the bran layer and endosperm individually and total water sorption should be equal to the sum of both of these corresponding water sorption. They provided following modified Peleg model for water sorption:

$$
M_{t}=\frac{t}{K_{1 b}+K_{2 b} t}+\frac{t}{K_{1 e}+K_{2 e} t}
$$

Where $t$ is steeping time (hours), $\mathrm{M}_{\mathrm{t}}$ is moisture content (dry basis), $K_{1 b} \& K_{2 b}$ are Peleg's constant for the outer bran layer and $K_{1 e} \& K_{2 e}$ are Peleg's constant for endosperm. Here initial moisture content $\mathrm{M}_{0}$ is assumed to be zero because here water absorbed in comparison to initial moisture content is considered.

Apart from Peleg's model, following sigmoidal model was also utilized for the understanding of basic diffusivity of water during hydration [28]:

$$
M_{t}=\frac{M_{s}}{1+\exp [-k \cdot(t-\tau)]}
$$

Where $t$ is steeping time (min), $M_{t}$ is moisture content (dry basis) at time $t, M_{s}$ is saturation moisture content (dry basis), $k$ is a constant rate of rehydration $\left(\mathrm{min}^{-1}\right)$ and $\tau$ is soaking time (min) at which grain moisture content is half of saturation moisture content.

Peleg's model and sigmoidal model, being empirical models ignore the elementary stages of mass transfer and provide no information regarding the water transportation mechanism. Both models ignore basic grain dimension and physical changes occurring during the hydration process. To overcome these shortcomings, Omoto et al. [31] proposed a phenomenological model which consider theoretical assumption as well as the elementary stage of mass transfer. Considering water concentration as uniform inside the grain initially, Omoto proposed following mass transfer balance equation:

$$
\frac{d\left(\rho_{A} V\right)}{d t}=N_{A} A
$$

Here right side represents the rate of change of water mass inside the grain with respect to time $t$ while the left side represents water mass flow flux. $N_{A}$ is water flow $\left(\mathrm{g} / \mathrm{cm}^{2} \mathrm{~h}\right), A$ is the surface area of the grain, $\rho_{A}$ is the concentration of water $\left(\mathrm{g} / \mathrm{cm}^{3}\right)$ and $V$ is grain volume $\left(\mathrm{m}^{3}\right)$

Convective water mass flow could be written as

$$
N_{A}=K_{s}\left(\rho_{e q}-\rho_{A}\right)
$$

Where $K_{S}$ is the overall mass transfer coefficient $(\mathrm{cm} / \mathrm{h})$, and $\rho_{e q}$ is the equilibrium water concentration $\left(\mathrm{g} / \mathrm{cm}^{3}\right)$ in the grain. 
Assuming spherical geometry of the grain with constant volume above mass transfer equation (10) could be written as:

$$
\frac{d\left(\rho_{A} V\right)}{d t}=\frac{3 K_{S}}{r}\left(\rho_{e q}-\rho_{A}\right)
$$

Where $r$ grain radius $(\mathrm{cm})$ is The analytical solution of the above Omoto model assuming $\mathrm{K}_{\mathrm{s}}$ as constant is presented as [16]:

$$
\rho_{A}(t)=\rho_{e q}-\left(\rho_{e q}-\rho_{A o}\right) \exp \left(-\frac{3 K_{S} t}{r}\right)
$$

For statistical analysis of the results, XLSTAT (trial version) and Microsoft EXCEL were used. All the experiments were conducted in triplicate for all samples. The determination coefficient $\left(\mathrm{R}^{2}\right)$ and the root mean square error (RMSE) were used to assess the quality of approximation of considered model and experimental data.

\section{RESULTS AND DISCUSSION}

\section{A. Physical Properties}

Major physical characteristics of pearl millet and finger millet grains are given in Table 1 . The measured length, width, height and geometric mean diameter of the pearl millet grain was $3.363 \pm 0.46,2.265 \pm 0.23,2.08 \pm 0.18$ and $2.56 \pm 0.22 \mathrm{~mm}$, respectively. The results are in a similar range with the previous studies that stated the average length, width and height of pearl millet grain was 2.8 to $3.7 \mathrm{~mm}, 1.7$ to 3.3 $\mathrm{mm}$ and 1.4 to $2.1 \mathrm{~mm}$ respectively[34],[35]. Similarly, for finger millet grain, values were $1.72 \pm 0.16,1.7 \pm 0.13,1.61 \pm$ $0.19,1.675 \pm 0.33$ respectively, which are close to the range reported by Ramashia et al[36]. The 1000 grain weight was $10.58 \pm 0.29$ gm and $3 \pm 0.06$ gm respectively for pearl millet and finger millet kernels.

Table 1. Average Values Of Physical Analysis Of Pearl Millet And Finger Millet

\begin{tabular}{|l|l|l|}
\hline Parameter & $\begin{array}{l}\text { Pearl } \\
\text { millet }\end{array}$ & $\begin{array}{l}\text { Finger } \\
\text { millet }\end{array}$ \\
\hline Whole seed weight (g) & 0.01058 & 0.003 \\
\hline Length (mm) & 3.363 & 1.72 \\
\hline Width $(\mathrm{mm})$ & 2.265 & 1.7 \\
\hline Thickness $(\mathrm{mm})$ & 2.08 & 1.61 \\
\hline Geometric diameter $(\mathrm{mm})$ & 2.509302 & 1.675111 \\
\hline Degree of sphericity & 0.74615 & 0.973901 \\
\hline Surface $\left(\mathrm{mm}^{2}\right)$ & 16.93138 & 8.612186 \\
\hline Volume $\left(\mathrm{mm}^{3}\right)$ & 6.125013 & 2.37465 \\
\hline Moisture content (d.b.) & $11.706 \%$ & $12.007 \%$ \\
\hline True density $\left(\mathrm{g} / \mathrm{cm}^{3}\right)$ & 1.45 & 1.48 \\
\hline
\end{tabular}

\section{B. Water absorption kinetics}

During the hydration process, the change in moisture content (on a dry weight basis) and volume (percentage) for pearl millet and finger millet were calculated at the mentioned five different steeping temperatures are shown in figure 1 and figure 2. As observed, the increase in water absorption is directly related to the temperature increase. Though at a higher temperature after initial hydration, water absorption is less compared to a lower temperature. This is due to a high rate of water diffusion at a higher temperature, which causes grain to reach its equilibrium stat faster. Similar behavior was observed in other studies [18],[19],[37]. As indicated in figure 1 , as hydration progresses the initial rate of water absorption is higher and then slowly goes to down as grain moisture content approach towards equilibrium. There is a decrease in driving force which is responsible for water transfer inside the grain. A similar effect was also reported during water steeping of sorghum, rice, corn, and lentil [19],[23],[38].

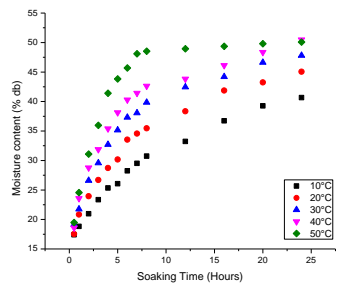

(a)

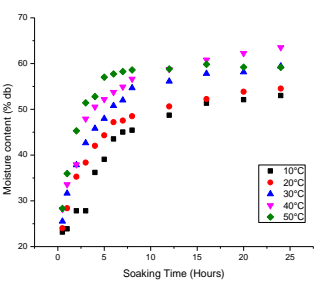

(b)
Fig 1. Effect Of Time And Temperature On Moisture Gain Of Pearl Millet Grain And Finger Millet Grain

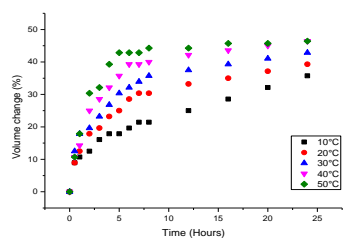

(a)

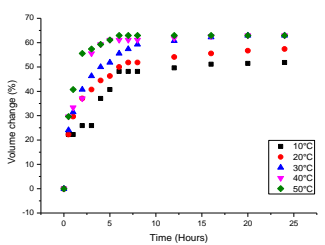

(b)
Fig 2. Effect of time and temperature on volume change in Pearl millet grain and finger millet grain

\section{Fitting of model equations}

The experimental data of moisture content (dry basis) during water absorption was fitted to Peleg's equation. The plot between $t /\left(M_{t}-M_{0}\right)$ versus steeping time (t) allows the studying of Peleg's constants i.e. Peleg's rate constant $\left(\mathrm{K}_{1}\right)$ and capacity constant $\left(\mathrm{K}_{2}\right)$ (figure 3 ). The values of these Peleg constants at mentioned temperatures are presented in Table 2. The competence of the equation for describing the water absorption kinetics could be confirmed by the coefficient of determination $\left(\mathrm{R}^{2}\right)$ values, which are greater than 0.97 and 0.98 for pearl millet and finger millet respectively for the studied temperature range.

In present work, values of Peleg's rate constant $\left(\mathrm{K}_{1}\right)$ were inversely correlated to the temperature. It indicates that at higher temperatures there is an increase in water absorption rate, which gradually goes down with time (figure 4). This result is in agreement with previous studies on sorghum [39] and finger millet [37].

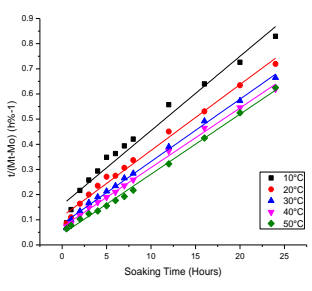

(a)

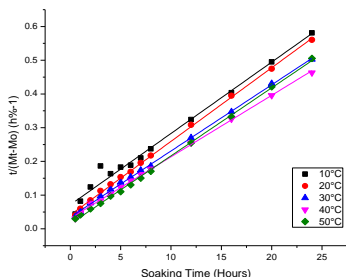

(b)
Fig 3. Application of Peleg's equation to the experimental data on Pearl millet and Finger millet

It is also observed that the Peleg's capacity constant $\mathrm{K}_{2}$ for pearl millet and finger millet kernels can be a function of temperature at a lower temperature (Figure 5). Similar results have been reported for chickpea [18], acha grain [29], amaranth grain [40], sorghum [39] and finger millet [37].

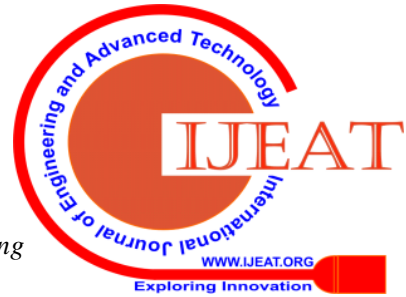


The constant $\mathrm{K}_{2}$ decreased from 0.0295 to 0.0236 for pearl millet and from 0.0211 to 0.0182 for finger millet, while the steeping temperature $(T)$ increased from 10 to $40^{\circ} \mathrm{C}$ (Table 2).

This is due to increase of temperature resulting into increase in water absorption capacity of pearl millet and finger millet. But constant $\mathrm{K}_{2}$ increases slightly as steeping temperature increases further from $40^{\circ} \mathrm{C}$ to $50^{\circ} \mathrm{C}$ which could be the result of soluble solid loss during the steeping process for prolong duration at a higher temperature [26].

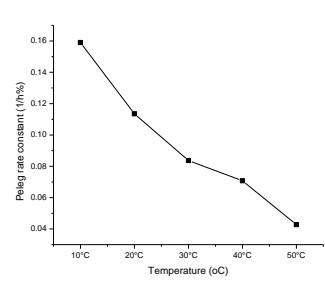

(a)

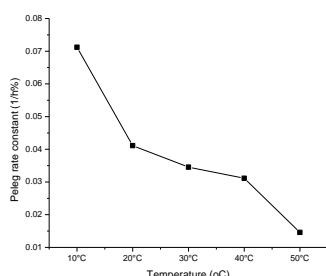

(b)
Fig 4. Effect Of Steeping Temperature On The Peleg Rate Constant (K1) (1/H\%) On Pearl Millet And Finger Millet

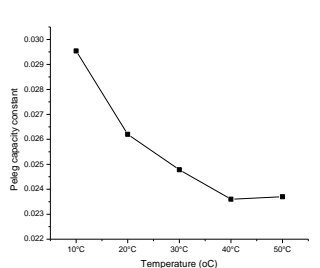

(a)

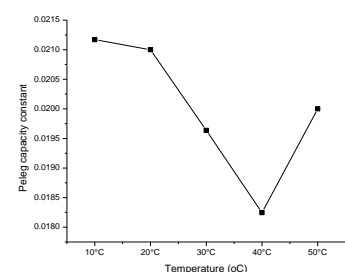

(b)
Fig 5. Effect of steeping temperature on the Peleg's Capacity Constant $\left(\mathrm{K}_{2}\right)\left(\%^{-1}\right)$ on Pearl millet and Finger Millet

The water absorption capacity of grain shows an inverse relation with capacity constant. As time processed to infinite, the saturation moisture content $\left(M_{s}\right)$ could be calculated by equation 5 as:

$$
M_{S}=M_{0}+\frac{1}{K_{2}}
$$

Table 2. Assessment of the parameters and goodness of fit for the Peleg model for Pearl millet and Finger Millet

\begin{tabular}{|l|l|l|l|l|r|l|}
\hline Sample & $\mathrm{T}\left({ }^{\circ} \mathrm{C}\right)$ & $\mathrm{K}_{1}$ & $\mathrm{~K}_{2}$ & $\mathrm{M}_{\mathrm{s}}$ & \multicolumn{1}{l|}{$\mathrm{M}_{\mathrm{i}}$} & $\mathrm{R}^{2}$ \\
\hline \multirow{4}{*}{$\begin{array}{c}\text { Pearl } \\
\text { millet }\end{array}$} & $10^{\circ} \mathrm{C}$ & 0.159 & 0.029 & 45.562 & 6.28 & 0.97 \\
\cline { 2 - 7 } & $20^{\circ} \mathrm{C}$ & 0.114 & 0.026 & 49.877 & 8.8 & 0.98 \\
\cline { 2 - 7 } & $30^{\circ} \mathrm{C}$ & 0.084 & 0.025 & 52.065 & 11.97 & 0.99 \\
\cline { 2 - 7 } & $40^{\circ} \mathrm{C}$ & 0.071 & 0.024 & 53.939 & 14.14 & 0.99 \\
\cline { 2 - 7 } & $50^{\circ} \mathrm{C}$ & 0.043 & 0.024 & 53.815 & 23.4 & 0.99 \\
\hline \multirow{4}{*}{$\begin{array}{l}\text { Finger } \\
\text { millet }\end{array}$} & $10^{\circ} \mathrm{C}$ & 0.071 & 0.021 & 59.247 & 14.05 & 0.98 \\
\cline { 2 - 7 } & $20^{\circ} \mathrm{C}$ & 0.041 & 0.021 & 57.809 & 24.33 & 0.99 \\
\cline { 2 - 7 } & $30^{\circ} \mathrm{C}$ & 0.034 & 0.019 & 62.936 & 28.96 & 0.99 \\
\cline { 2 - 7 } & $40^{\circ} \mathrm{C}$ & 0.031 & 0.018 & 66.818 & 32.11 & 0.99 \\
\cline { 2 - 7 } & $50^{\circ} \mathrm{C}$ & 0.014 & 0.02 & 61.56 & 68.54 & 0.99 \\
\hline
\end{tabular}

Saturation moisture content increases as steeping temperature increases from $10^{\circ} \mathrm{C}$ to $40^{\circ} \mathrm{C}$ due to increase in water absorption capacity of millets but it decreases as steeping temperature rises from $40^{\circ} \mathrm{C}$ to $50^{\circ} \mathrm{C}$ due to soluble solid loss. The value of saturation constant of pearl millet and finger millet kernel is given in table 2 .

Initial rate of water absorption $\left(M_{i}\right)$ could be calculated by deriving equation 5 with respect to time and evaluating moisture content at the very beginning of the hydration process. Initial water absorption rate is directly related to inverse of Peleg's rate constant. It increases rapidly as steeping temperature increases, especially when temperature increases from $40^{\circ} \mathrm{C}$ to $50^{\circ} \mathrm{C}$ (Table 2)

Table 3. Assessment of the parameters and goodness of fit for the Modified Peleg model.

\begin{tabular}{|c|c|c|c|c|c|c|}
\hline $\begin{array}{l}\text { Sampl } \\
\text { e }\end{array}$ & $\mathrm{T}$ & $\mathrm{K}_{1 \mathrm{~b}}$ & $\mathrm{~K}_{2 \mathrm{~b}}$ & $\mathrm{~K}_{1 \mathrm{e}}$ & $\mathrm{K}_{2 \mathrm{e}}$ & $\mathrm{R}^{2}$ \\
\hline \multirow{5}{*}{$\begin{array}{l}\text { Pearl } \\
\text { millet }\end{array}$} & $10^{\circ} \mathrm{C}$ & 0.179 & 0.031 & 8.192 & 0.236 & 0.97 \\
\hline & $20^{\circ} \mathrm{C}$ & 0.242 & 0.027 & 0.044 & 0.157 & 0.99 \\
\hline & $30^{\circ} \mathrm{C}$ & -0.067 & 0.422 & 0.114 & 0.025 & 0.99 \\
\hline & $40^{\circ} \mathrm{C}$ & 0.074 & 0.052 & 0.246 & 0.041 & 0.99 \\
\hline & $50^{\circ} \mathrm{C}$ & 0.076 & 0.036 & 0.129 & 0.061 & 0.97 \\
\hline \multirow{5}{*}{$\begin{array}{l}\text { Finger } \\
\text { millet }\end{array}$} & $10^{\circ} \mathrm{C}$ & 0.086 & 0.02 & -1.117 & 2.402 & 0.97 \\
\hline & $20^{\circ} \mathrm{C}$ & -0.071 & 0.369 & 0.054 & 0.023 & 0.99 \\
\hline & $30^{\circ} \mathrm{C}$ & -0.008 & 0.188 & 0.053 & 0.021 & 0.99 \\
\hline & $40^{\circ} \mathrm{C}$ & -0.116 & 0.403 & 0.039 & 0.019 & 0.98 \\
\hline & $50^{\circ} \mathrm{C}$ & 0.061 & 0.06 & 0.029 & 0.028 & 0.98 \\
\hline
\end{tabular}

Table 3 represent parameter values for modified Peleg equation. The $\mathrm{R}^{2}$ values greater than 0.97 for both pearl millet and finger millet confirms the competence of the equation for describing the hydration kinetics of grains within the studied temperature range. There is no significant change in $\mathrm{R}^{2}$ compared to Peleg equation. This could be due to the small size of the grain, and thinner bran layer which reduces the heterogeneity of structure

Table 4. Assessment of the parameters and goodness of fit for the Sigmoidal model.

\begin{tabular}{|l|l|l|r|r|r|}
\hline \multirow{4}{*}{ Sample } & $\mathrm{T}\left({ }^{\circ} \mathrm{C}\right)$ & $\pi(\mathrm{min})$ & $\begin{array}{c}\mathrm{K} \\
(\mathrm{cm} / \mathrm{min})\end{array}$ & \multicolumn{1}{l|}{$\mathrm{R}^{2}$} & \multicolumn{1}{l|}{ RMSE } \\
\hline \multirow{4}{*}{$\begin{array}{l}\text { Pearl } \\
\text { millet }\end{array}$} & $10^{\circ} \mathrm{C}$ & $115 \pm 5$ & 0.003 & 0.989 & 0.837 \\
\cline { 2 - 6 } & $20^{\circ} \mathrm{C}$ & $100 \pm 5$ & 0.004 & 0.983 & 1.153 \\
\cline { 2 - 6 } & $30^{\circ} \mathrm{C}$ & $90 \pm 4$ & 0.004 & 0.981 & 1.372 \\
\cline { 2 - 6 } & $40^{\circ} \mathrm{C}$ & $80 \pm 4$ & 0.005 & 0.96 & 2.111 \\
\cline { 2 - 6 } & $50^{\circ} \mathrm{C}$ & $65 \pm 3$ & 0.009 & 0.997 & 0.713 \\
\hline \multirow{4}{*}{$\begin{array}{l}\text { Finger } \\
\text { millet }\end{array}$} & $10^{\circ} \mathrm{C}$ & $110 \pm 5$ & 0.005 & 0.982 & 1.574 \\
\cline { 2 - 6 } & $20^{\circ} \mathrm{C}$ & $56 \pm 2$ & 0.006 & 0.98 & 1.647 \\
\cline { 2 - 6 } & $30^{\circ} \mathrm{C}$ & $52.5 \pm 2$ & 0.006 & 0.984 & 1.529 \\
\cline { 2 - 6 } & $40^{\circ} \mathrm{C}$ & $51 \pm 2$ & 0.006 & 0.968 & 2.297 \\
\cline { 2 - 6 } & $50^{\circ} \mathrm{C}$ & $36 \pm 52$ & 0.013 & 0.992 & 0.989 \\
\hline
\end{tabular}

Constant rate of hydration $(k)$ for the sigmoidal model is given in table 4 along with the coefficient of determination $\left(R^{2}\right)$ for each temperature, which increases with increase in temperature. This increase in the value of the constant rate of hydration is relatively slow as temperature increase from $10^{\circ} \mathrm{C}$ to $40^{\circ} \mathrm{C}$, with almost stagnant for the temperature change from $20^{\circ} \mathrm{C}$ to $30^{\circ} \mathrm{C}$. But as temperature increase to $50^{\circ} \mathrm{C}$ from $40^{\circ} \mathrm{C}$, the value of the rate of hydration constant increase by $80 \%$ for pearl millet and $100 \%$ for finger millet.

Effect of temperature and steeping time on water concentration inside the grain is given in figure 6 . These data were fitted in Omoto model. 
Table 5 represents the value of mass transfer coefficient also known as diffusion coefficient $\left(\mathrm{K}_{\mathrm{S}}\right)$ and coefficient of determination $\left(\mathrm{R}^{2}\right)$ for each temperature. The $\mathrm{R}^{2}$ values greater than 0.98 and 0.96 for pearl millet and finger millet respectively indicate a good fit for the model to experimental data. As temperature rises the value of diffusion coefficient also increases, which indicate the increased initial velocity of water desorption of grains at higher temperatures [30],[31]. Despite the importance of diffusion coefficient on water uptake rate during steeping, very less work has been reported for Omoto model.

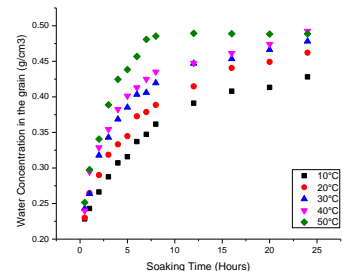

(a)

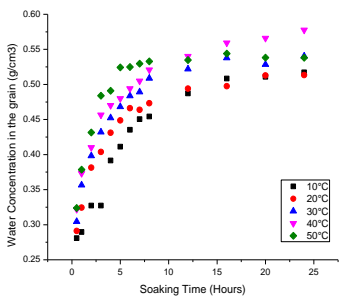

(b)
Fig 6. Effect Of Time And Temperature On Water Concentration In Pearl Millet Grain And Finger Millet Grain

Table 5. Assessment Of The Parameters And Goodness Of Fit For The Omoto Model

\begin{tabular}{|l|l|l|l|l|l|}
\hline Sample & $\mathrm{T}\left({ }^{\circ} \mathrm{C}\right)$ & $\rho_{\mathrm{EQ}}$ & $\begin{array}{l}\mathrm{K}_{\mathrm{S}} \\
(\mathrm{cm} / \mathrm{min})\end{array}$ & $\mathrm{R}^{2}$ & $\mathrm{RMSE}$ \\
\hline \multirow{4}{*}{$\begin{array}{l}\text { Pearl } \\
\text { millet }\end{array}$} & $10^{\circ} \mathrm{C}$ & 0.428 & 0.012986 & 0.988 & 1.545 \\
\cline { 2 - 6 } & $20^{\circ} \mathrm{C}$ & 0.462 & 0.014366 & 0.985 & 0.021 \\
\cline { 2 - 6 } & $30^{\circ} \mathrm{C}$ & 0.478 & 0.018021 & 0.994 & 0.020 \\
\cline { 2 - 6 } & $40^{\circ} \mathrm{C}$ & 0.492 & 0.019033 & 0.989 & 0.026 \\
\cline { 2 - 6 } & $50^{\circ} \mathrm{C}$ & 0.488 & 0.029505 & 0.986 & 0.011 \\
\hline \multirow{4}{*}{$\begin{array}{l}\text { Finger } \\
\text { millet }\end{array}$} & $10^{\circ} \mathrm{C}$ & 0.517 & 0.011351 & 0.963 & 0.025 \\
\cline { 2 - 6 } & $20^{\circ} \mathrm{C}$ & 0.513 & 0.018552 & 0.980 & 0.026 \\
\cline { 2 - 6 } & $30^{\circ} \mathrm{C}$ & 0.540 & 0.019735 & 0.969 & 0.030 \\
\cline { 2 - 6 } & $40^{\circ} \mathrm{C}$ & 0.577 & 0.017371 & 0.960 & 0.042 \\
\cline { 2 - 6 } & $50^{\circ} \mathrm{C}$ & 0.538 & 0.033195 & 0.973 & 0.017 \\
\hline
\end{tabular}

\section{Activation energy}

As per Fick's law, effective diffusivity is directly proportionate to the square of grain radius. Due to comparatively high variation in grain volume during the hydration process and longer process time, Fick's law of diffusion cannot be utilized for calculation of effective diffusivity and activation energy. However, Peleg rate constant could be linked to the diffusion coefficient as it shows a linear relationship with temperature. Sopade et.al. proposed instead of effective diffusivity, reciprocal of $\mathrm{K}_{1}$ could be used in the Arrhenius equation temperature as [20]:

$$
\frac{1}{K_{1}}=K_{o} \exp \frac{E_{a}}{R T}
$$

Values of Peleg rate constant and temperature were fitted in the above equation for determination of constants. The coefficient of determination $\left(\mathrm{R}^{2}\right)$ for the above equation was 0.961 and 0.893 for pearl millet and finger millet respectively, which indicate a good fit for the model to experimental data for pearl millet. The predicted value of activation energy was $25.97 \mathrm{~kJ} / \mathrm{mol}$ and $32.36 \mathrm{~kJ} / \mathrm{mol}$ respectively for pearl millet and finger millet.

\section{CONCLUSION}

The empirical and phenomenological models were evaluated for water absorption kinetics of pearl millet and finger millet as a function of hydration temperature. Gain in grain volume and water absorption rate remains high during the initial phase of hydration at a higher temperature while at lower temperature this increment is gradual. At higher temperature, the water absorption rate decreases with time. Both Omoto model and Peleg model could be utilized for describing the hydration process. Peleg rate constant decreases linearly as temperature increases while Peleg capacity constant shows a slight increase at a higher temperature. Diffusivity coefficient of Omoto model increases as hydration temperature increases with major increment at a higher temperature. While the hydration rate constant of the sigmoidal model remains almost similar at lower temperature and sudden increase at a higher temperature. Due to considerable small grain size, the change in grain radius during the hydration process is significant, hence first order equation based upon Fick's law and rate of hydration from the sigmoidal model could not be utilized for calculation of effective diffusivity. Although reciprocal of Peleg rate constant could be used in place of effective diffusivity in the Arrhenius equation for calculation of activation energy, as it is inversely related to hydration temperature.

\section{REFERENCES}

1. R. Hoover, G. Swamidas, L. S. Kok, and T. Vasanthan, "Composition and physicochemical properties of starch from pearl millet grains," Food Chem., vol. 56, no. 4, pp. 355-367, 1996.

2. a. a. Abdalla, a. H. El Tinay, B. E. Mohamed, and a. H. Abdalla, "Proximate composition, starch, phytate and mineral contents of 10 pearl millet genotypes," Food Chem., vol. 63, no. 2, pp. 243-246, 1998.

3. D. Chandra, S. Chandra, and A. K. Sharma, "Review of Finger millet ( Eleusine coracana ( L .) Gaertn ): A power house of health benefiting nutrients," Food Sci. Hum. Wellness, vol. 5, no. 3, pp. 149-155, 2016

4. A. Chandrasekara, M. Naczk, and F. Shahidi, "Effect of processing on the antioxidant activity of millet grains," Food Chem., vol. 133, no. 1, pp. 1-9, 2012.

5. A. Chandrasekara and F. Shahidi, "Determination of antioxidant activity in free and hydrolyzed fractions of millet grains and characterization of their phenolic profiles by HPLC-DAD-ESI-MS n,” J. Funct. Foods, vol. 3, no. 3, pp. 144-158, 2011.

6. A. Gull, K. Prasad, and P. Kumar, "Evaluation of functional, antinutritional, pasting and microstructural properties of Millet flours,' J. Food Meas. Charact., vol. 10, no. 1, pp. 96-102, 2016.

7. F. O. Sade, "Proximate, antinutritional factors and functional properties of processed pearl millet (Pennisetum glaucum)," Journal of food technology technology, vol. 7, no. 3. pp. 92-97, 2009.

8. M. a. Osman, "Effect of traditional fermentation process on the nutrient and antinutrient contents of pearl millet during preparation of Lohoh," J. Saudi Soc. Agric. Sci., vol. 10, no. 1, pp. 1-6, 2011.

9. A. Tiwari, S. K. K. Jha, R. K. K. Pal, S. Sethi, and L. Krishan, "EFFECT OF PRE-MILLING TREATMENTS ON STORAGE STABILITY OF PEARL MILLET FLOUR,” J. Food Process. Preserv., vol. 38, no. 3, pp. 1215-1223, Jun. 2014.

10. V. Venkateswaran and G. Vijayalakshmi, "Finger millet (Eleusine coracana) - an economically viable source for antihypercholesterolemic metabolites production by Monascus purpureus.," J. Food Sci. Technol., vol. 47, no. 4, pp. 426-431, Aug. 2010. 
11. P. M. M. Pradeep and Y. N. Sreerama, "Impact of processing on the phenolic profiles of small millets: Evaluation of their antioxidant and enzyme inhibitory properties associated with hyperglycemia," Food Chem., vol. 169, pp. 455-463, 2015.

12. J. M. Awika, C. M. McDonough, and L. W. Rooney, "Decorticating sorghum to concentrate healthy phytochemicals.," J. Agric. Food Chem., vol. 53, no. 16, pp. 6230-4, Aug. 2005.

13. C. C. Nwasike, "Effect of Cultivar, Steeping, and Malting on Tannin, Total Polyphenol , and Cyanide Content of Nigerian Sorghum," Development, vol. 66, o. 2, pp. 87-89, 1989.

14. J. K. CHAVAN, S. S. KADAM, and D. K. SALUNKHE, "Changes in Tannin, Free Amino Acids, Reducing Sugars, and Starch During Seed Germination of Low and High Tannin Cultivars of Sorghum,” J. Food Sci., vol. 46, no. 2, pp. 638-639, Mar. 1981.

15. A. L. Oliveira, B. G. Colnaghi, E. Z. da Silva, I. R. Gouvêa, R. L. Vieira, and P. E. D. Augusto, "Modelling the effect of temperature on the hydration kinetic of adzuki beans (Vigna angularis)," J. Food Eng., vol. 118, no. 4, pp. 417-420, Oct. 2013.

16. D. J. Nicolin, R. M. Neto, P. R. Paraíso, R. M. M. Jorge, and L. M. M. Jorge, "Analytical solution and experimental validation of a model for hydration of soybeans with variable mass transfer coefficient," J. Food Eng., vol. 149, pp. 17-23, 2015.

17. V. S. Sharanagat, V. Kansal, and K. Kumar, "Modeling the effect of temperature on the hydration kinetic whole moong grain," J. Saudi Soc. Agric. Sci., vol. 17, no. 3, pp. 268-274, 2018.

18. S. M. Shafaei, A. A. Masoumi, and H. Roshan, "Analysis of water absorption of bean and chickpea during soaking using Peleg model," J. Saudi Soc. Agric. Sci., vol. 15, no. 2, pp. 135-144, 2016.

19. M. Kashiri, A. Daraei Garmakhany, and A. A. Dehghani, "Modelling of sorghum soaking using artificial neural networks (MLP)," Qual. Assur. Saf. Crop. Foods, vol. 4, no. 4, pp. 179-184, 2012.

20. P. A. Sopade, E. S. Ajisegiri, and M. H. Badau, "The use of Peleg's equation to model water absorption in some cereal grains during soaking,” J. Food Eng., vol. 15, no. 4, pp. 269-283, 1992.

21. P. A. Sopade, P. Y. Xun, P. J. Halley, and M. Hardin, "Equivalence of the Peleg, Pilosof and Singh-Kulshrestha models for water absorption in food," J. Food Eng., vol. 78, no. 2, pp. 730-734, 2007.

22. D. J. Nicolin, T. C. V. Balbinoti, R. M. M. Jorge, and L. M. de M. Jorge, "Generalization of a lumped parameters model using fractional derivatives applied to rice hydration," J. Food Process Eng., no. September, p. e12641, 2017.

23. D. J. Nicolin, B. C. Marques, T. C. V. Balbinoti, R. M. M. Jorge, and L. M. de M. Jorge, "Modeling rice and corn hydration kinetic by Nicolin-Jorge model," J. Food Process Eng., no. December 2016, pp. 1-7, 2017.

24. F. D. Montanuci, C. A. Perussello, L. M. de Matos Jorge, and R. M. M. Jorge, "Experimental analysis and finite element simulation of the hydration process of barley grains," J. Food Eng., vol. 131, pp. 44-49, Jun. 2014.

25. M. R. Coutinho, E. S. Omoto, W. A. Dos Santos Conceição, C. M. G. Andrade, and L. M. M. Jorge, "Evaluation of two mathematical models applied to soybean hydration," Int. J. Food Eng., vol. 6, no. 6, 2010.

26. M. Turhan, S. Sayar, and S. Gunasekaran, "Application of Peleg model to study water absorption in chickpea during soaking," J. Food Eng., vol. 53, no. 2, pp. 153-159, 2002.

27. J. R. Matias, R. C. Ribeiro, C. A. Aragão, G. G. L. Araújo, and B. F. Dantas, "Physiological changes in osmo and hydroprimed cucumber seeds germinated in biosaline water | Modificações fisiológicas em sementes de pepino osmo e hidrocondicionadas germinadas em água biossalina," J. Seed Sci., vol. 37, no. 1, 2015.

28. K. G. Kaptso, Y. N. Njintang, A. E. Komnek, J. Hounhouigan, J. Scher, and C. M. F. Mbofung, "Physical properties and rehydration kinetics of two varieties of cowpea (Vigna unguiculata) and bambara groundnuts (Voandzeia subterranea) seeds," J. Food Eng., vol. 86, no. 1, pp. 91-99, 2008.

29. T. Y. Tunde-Akintunde, "Water Absorption Characteristics of Nigerian Acha (Digitaria exilis),” Int. J. Food Eng., vol. 6, no. 5, 2010.

30. M. Aparecida, B. Soares, L. Mario, D. M. Jorge, and F. D. Montanuci, "Drying kinetics of barley grains and effects on the germination index," Food Sci. Technol. Campinas, vol. 36, no. 4, pp. 638-645, 2016.

31. E. S. Omoto, C. M. G. Andrade, R. M. M. Jorge, M. R. Coutinho, P. R. Paraíso, and L. M. de M. Jorge, "Modelagem matemática e análise da hidratação de grãos de ervilha," Ciência e Tecnol. Aliment., vol. 29, no. 1, pp. 12-18, Mar. 2009.

32. M. PELEG, "An Empirical Model for the Description of Moisture Sorption Curves," Journal of Food Science, vol. 53, no. 4. pp. 1216-1217, 1988.

33. O. Paquet-Durand, V. Zettel, R. Kohlus, and B. Hitzmann, "Optimal design of experiments and measurements of the water sorption process of wheat grains using a modified Peleg model," J. Food Eng., vol. 165, pp. 166-171, 2015.

34. M. H. Badau, I. Nkama, and C. O. Ajalla, "International Journal of Food Properties physico-chemical characteristics of pearl millet cultivars grown in northern Nigeria," Int. J. Food Prop., vol. 5:1, no. August 2015, pp. 37-47, 2007.

35. E. A. Baryeh, "Physical properties of millet," J. Food Eng., vol. 51, pp. 39-46, 2002.

36. S. E. Ramashia, E. T. Gwata, S. Meddows-Taylor, T. A. Anyasi, and A. I. O. Jideani, "Some physical and functional properties of finger millet (Eleusine coracana) obtained in sub-Saharan Africa," Food Res. Int., vol. 104, no. September, pp. 110-118, 2018.

37. S. B. Swami, N. J. Thakor, and H. S. Gurav, "Effect of soaking and malting on finger millet (EleusineCoracana) grain," vol. 15, no. 1, pp 194-200, 2013.

38. M. Maneesh Kumar, K. Prasad, T. Sarat Chandra, and S. Debnath, "Evaluation of physical properties and hydration kinetics of red lentil (Lens culinaris) at different processed levels and soaking temperatures," J. Saudi Soc. Agric. Sci., 2016.

39. M. Kashiri, M. Kashaninejad, and N. Aghajani, "Modeling water absorption of sorghum during soaking," Lat. Am. Appl. Res., vol. 40, no. 4, pp. 383-388, 2010.

40. A. C. Resio, R. J. Aguerre, and C. Suarez, "Hydration kinetics of amaranth grain,” J. Food Eng., vol. 72, no. 3, pp. 247-253, 2006.

\section{AUTHORS PROFILE}

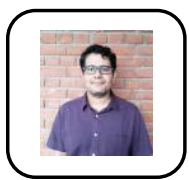

Ankit Paliwal has done M.Tech in food Technology \& Biochemical Engineering from Jadavpur University, Kolkata. Currently Working at Amity University Uttar Pradesh, Noida as Assistant Professor. He has more than a year work experience in brewing industry and more than 8 years' experience in research and academics.

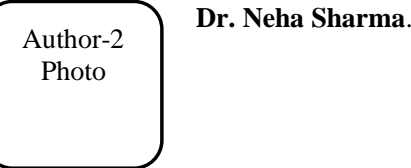

